\title{
Logika Fuzzy untuk Perilaku Dinamis pada Sistem Crafting dalam Game Pembelajaran Aritmatika
}

\author{
Andrean Nugraha Fajero', Hanny Haryanto², T. Sutojo ${ }^{3}$, Edy Mulyanto ${ }^{4}$ \\ Program Studi Teknik Informatika, Fakultas Ilmu Komputer \\ Universitas Dian Nuswantoro \\ Semarang, Indonesia \\ e-mail: ${ }^{1}$ andreannugrahafajero@gmail.com, ${ }^{2}$ hanny.haryanto@dsn.dinus.ac.id, ${ }^{3}$ tsutojo@gmail.com, \\ ${ }^{4}$ edy.mulyanto@dsn.dinus.ac.id
}

Diajukan: 26 Februari 2020; Direvisi: 18 Maret 2020; Diterima: 31 Maret 2020

\begin{abstract}
Abstrak
Sistem crafting sebagai mekanik utama dapat menjadi solusi mengatasi kemonotonan gameplay dalam suatu serious game. Sistem crafting dapat diaplikasikan dalam game aritmatika yang mempunyai banyak materi berupa perhitungan. Permasalahan yang terjadi adalah sistem crafting yang kombinasi itemnya sedikit dan sudah diketahui sebelumnya sehingga membuat pemain game cepat merasa bosan, oleh karena itu perlu dirancang sebuah sistem crafting yang dinamis menggunakan kecerdasan buatan. Logika fuzzy adalah metode dalam kecerdasan buatan yang dapat menangani permasalahan yang bersifat intuitif. Metode tersebut digunakan dalam penelitian ini untuk membuat hasil dari kombinasi item dalam sistem crafting menjadi lebih terlihat dinamis dan tidak monoton. Item yang dikombinasikan dalam penelitian ini berupa batuan dan menggunakan parameter masukan berupa nilai dari batuan dasar untuk perhitungan dalam menentukan kualitas batu yang dihasilkan. Sedangkan nama atau jenis batu baru yang dihasilkan ditentukan dari nama batuan dasar yang digunakan dan sudah ditentukan sebelumnya supaya terlihat lebih bervariasi. Sistem crafting ini akan diterapkan dalam serious game berupa game pendidikan aritmatika dasar. Hasil dari penelitian ini yaitu sistem fuzzy berhasil menciptakan batu baru dengan kualitas yang lebih variatif, tidak monoton dan lebih terlihat dinamis sesuai dengan nilai dari batu dasar yang digunakan untuk crafting.
\end{abstract}

Kata kunci: Serious game, Logika Fuzzy, Aritmatika dasar, Sistem crafting.

Crafting systems as the main mechanics can be a solution to overcome the monotony of gameplay in a serious game. Crafting system can be applied in arithmetic games that have a lot of material in the form of calculations. The problem that occurs is a crafting system that combines a few items and has been known beforehand so that it makes the game player quickly feel bored, therefore it is necessary to design a dynamic crafting system using artificial intelligence. Fuzzy logic is a method in artificial intelligence that can handle problems that are intuitive. The method is used in this study to make the results of the combination of items in the crafting system look more dynamic and not monotonous. The items combined in this study are stones and use input parameters in the form of values from bedrock for calculations in determining the quality of the stones produced. While the name or type of new stone produced is determined from the name of the bedrock used and predetermined so that it looks more varied. This crafting system will be applied in serious games in the form of basic arithmetic education games. The results of this study are that the fuzzy system has succeeded in creating new stones with a more varied quality, not monotonous and more dynamic according to the value of the basic stone used for crafting.

Keywords: Serious game, Fuzzy logic, Basic arithmetic, Crafting system.

\section{Pendahuluan}

Pelajaran matematika merupakan materi pelajaran wajib untuk jenjang pendidikan SD, SMP, dan SMA menurut lampiran Permendiknas No. 22 Tahun 2006 [1]. Pemberian pelajaran matematika sangat penting karena memiliki peran penting untuk pembentukan karakter siswa dalam berpikir logis, analitis, sistematis, kritis, dan kreatif [2]. Di Indonesia peminat pelajaran matematika termasuk rendah karena sering kali dianggap sebagai pelajaran yang sulit untuk dimengerti. Berdasarkan hasil survei 49 negara SEA pada 
tahun 2015 dari Trends in International Mathematics and Science Study dengan koordinir dari The International for Evaluation of Education Achievement mengenai kemampuan siswa usia 9 - 15 tahun dalam Matematika dan Sains, menyebutkan bahwa Indonesia menduduki peringkat ke-44 dengan skor 397 yang masih jauh dari skor rata-rata standar dari TIMSS yaitu 500 [3].

Metode pemberian soal-soal latihan tanpa menggunakan alat peraga atau media pembelajaran cenderung membosankan menjadikan proses belajar mengajar tidak interaktif dalam tahap pengenalan konsep dasar matematika [4]. UU tahun 2003 nomor 20 mengenai sistem pendidikan nasional yang mewajibkan setiap tenaga pendidik menciptakan suasana pendidikan yang kreatif, dinamis, dialogis, menyenangkan, dan bermakna [5]. Metode pembelajaran menggunakan teknologi memungkinkan untuk membantu peserta didik dalam memahami materi ajar dengan metode pembelajaran yang berbeda [6]. Berdasarkan hasil penelitian yang dilakukan oleh The Asian Parent Insights pada November 2014, sebanyak 98 persen dari 2.714 orang tua di Asia Tenggara mengizinkan anak dengan rentan usia $3-8$ tahun untuk mengakses teknologi berupa komputer, smartphone, atau tablet untuk tujuan edukasi. Namun kenyataannya menurut hasil survei sebagian besar putra-putri mereka menggunakan gadget/tablet tersebut untuk tujuan hiburan seperti game [7].

Game Edukasi merupakan genre game yang diciptakan untuk membantu pemain dalam memahami suatu topik tertentu [8]. Suatu topik dapat ter-visualisasi dengan nyata menggunakan game edukasi dibanding dengan metode edukasi konvensional yang kurang visualisasi. Dari kelebihan inilah game edukasi menjadi sangat menarik untuk dikembangkan. Penelitian yang dilakukan oleh mahasiswa Universitas Negeri Padang menyebutkan, terdapat hasil yang signifikan terhadap peningkatan kemampuan anak setelah adanya intervensi yaitu pemberian game edukasi sebagai media belajar siswa [9]. Edukasi yang dikemas dalam bentuk game mampu menarik minat pemain untuk terus memainkannya. Konten dinamis dalam game sangat berpengaruh untuk menciptakan rasa penasaran yang tinggi bagi pemain. Fitur crafting konten/item merupakan salah satu fitur yang membuat pemain tertarik pada suatu game.

Crafting system pada game berguna untuk membuat atau menciptakan suatu item baru dari penggabungan beberapa bahan yang dibutuhkan dari suatu item tersebut. Pemberian informasi komposisi bahan suatu item akan membuat pemain kurang penasaran karena pemain dapat langsung membuat suatu item dengan bahan yang sudah tersedia [10]. Hal ini dilakukan dengan menggunakan kecerdasan buatan dalam pembentukan suatu item ditujukan agar pemain dapat bereksperimen untuk membuat suatu item. Dengan adanya aktivitas eksperimen tersebut akan membuat pemain lebih penasaran untuk membuat susunan bahan yang tepat dari suatu item dalam fitur crafting tersebut.

Kecerdasan buatan memiliki beberapa metode salah satunya yaitu Fuzzy. Fuzzy logic merupakan suatu logika yang dapat berpikir seperti manusia dalam menentukan besaran yang tidak pasti seperti tidak tepat, kurang tepat, hampir tepat, atau sangat tepat [11]. Pemilihan tingkat kesulitan pada game membuat pemain yang baru bermain pada suatu game tidak tahu tingkat kemampuannya. Logika Fuzzy digunakan dalam pemodelan tingkat kesulitan bermain secara otomatis tanpa adanya pemilihan tingkat kesulitan oleh pemain pada game Wayang Ramayana [12]. Penelitian pada game Card Battle yang dilakukan oleh M. Sugeng Riadi, Erli Saputra, dan Daniel Udjulawa membuktikan bahwa perilaku musuh dapat ditentukan dari kondisi bermain pada game tersebut. Penerapan logika Fuzzy Sugeno terbukti efektif untuk pengambilan keputusan pada perilaku musuh dalam memilih kartu. Membuat item menjadi dinamis yang dapat menyesuaikan kebutuhan pemain dalam game bertema kebersihan sungai, juga menggunakan logika Fuzzy. Logika Fuzzy Mamdani digunakan sebagai metode pengambilan keputusan dan status bermain pemain dalam game sebagai parameter input untuk menghasilkan output item yang dapat beradaptasi sesuai item yang dibutuhkan oleh pemain [13].

Penelitian-penelitian di atas mengemukakan bahwa logika Fuzzy dapat membentuk perilaku dinamis pada elemen game. Permasalahan sistem crafting yang kombinasi itemnya sedikit dan sudah diketahui sebelumnya sehingga membuat pemain game cepat merasa bosan, dapat diselesaikan dengan merancang sebuah sistem crafting yang dinamis menggunakan kecerdasan buatan. Penelitian ini membahas tentang perancangan sebuah kecerdasan buatan menggunakan logika Fuzzy pada fitur Crafting untuk menentukan hasil yang dinamis dalam pengacakan item di Game Edukasi Aritmatika berbasis mobile. Saat proses crafting, pemain dituntut untuk bereksperimen dalam mengombinasi bahan-bahan yang tersedia dan menghasilkan item yang tepat untuk menjawab pertanyaan yang tersedia dan membukakan jalan pemain untuk sampai ke tempat tujuan di dalam permainan ini.

\section{Metode Penelitian}

Proses dalam sistem crafting harus dilalui dengan proses penggabungan dari beberapa item. Pada proses penentuan pengacakan item dibutuhkan beberapa parameter masukkan untuk mendapatkan suatu nilai. Dari nilai yang dihasilkan tersebut digunakan untuk menentukan level, nama dan kualitas item yang 
didapatkan. Kualitas item dibedakan menjadi 3 bagian yaitu kualitas lemah, sedang dan kuat. Hasil item yang didapat berdasarkan kombinasi item dengan jumlah 3 kombinasi batuan yang terdiri dari batuan dasar 1, batuan dasar 2, dan batuan magis. Kombinasi tidak dapat dilakukan dengan kondisi batuan dasar 1 dan batuan dasar 2 memiliki jenis yang sama. Contohnya, pemain memasukkan lava stone pada slot batuan dasar 1, pada slot batuan dasar 2 pemain juga memasukkan lava stone dengan tambahan batuan magis. Hal tersebut tidak akan menghasilkan batuan apa pun dan kombinasi tersebut akan otomatis ditolak oleh sistem di dalam game. Gambar 1 menunjukkan tahapan dalam menghasilkan item.

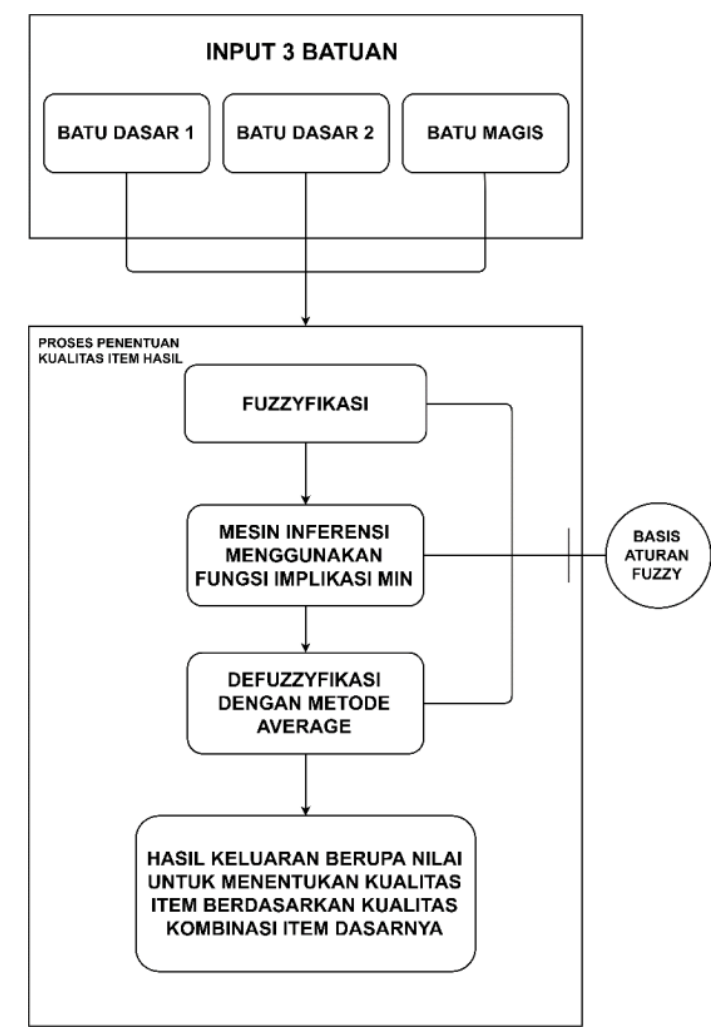

Gambar 1. Tahapan sistem crafting dinamis.

\subsection{Pembentukan Sistem Crafting dengan Logika Fuzzy}

Tahapan utama dalam pembentukan sistem Fuzzy terdiri dari tiga langkah, yaitu fuzzifikasi, inferensi, dan defuzzifikasi. Tahapan di dalam fuzzifikasi adalah pembentukan grafik keanggotaan untuk penentuan derajat keanggotaan masing-masing variabel. Fungsi segitiga dalam Fuzzy dapat diselesaikan dengan persamaan 1 berikut. Sedangkan fungsi trapezium ditunjukkan oleh persamaan 2.

$$
\begin{aligned}
& \text { Triangular }(x, a, b, c)=\left\{\begin{array}{l}
0, x<=a, x>=c \\
(x-a) /(b-a), a<x<=b \\
(c-x) /(c-b), b<x<=c
\end{array}\right. \\
& \text { Trapezium }(x, a, b, c, d)=\left\{\begin{array}{l}
0, x<=a, x>=d \\
(x-a) /(b-a), a<x<=b \\
1, b<x<=c \\
-(x-d) /(d-c), c<x<=d
\end{array}\right.
\end{aligned}
$$

Item crafting berupa batu yang dibagi dua jenis, yaitu batu dasar dan batu magis. Dalam batu dasar terdapat 5 jenis batuan dasar yang memiliki nama dan fungsi keanggotaan yang berbeda-beda untuk mendapatkan kombinasi item yang berbeda-beda untuk mendapatkan suatu item yang diinginkan. Setiap 
batuan dasar memiliki rentang nilai antara 0 - 100 untuk membedakan kualitas dari batuan tersebut. Gambar 2 adalah gambar grafik keanggotaan yang sudah ditentukan untuk batu dasar.

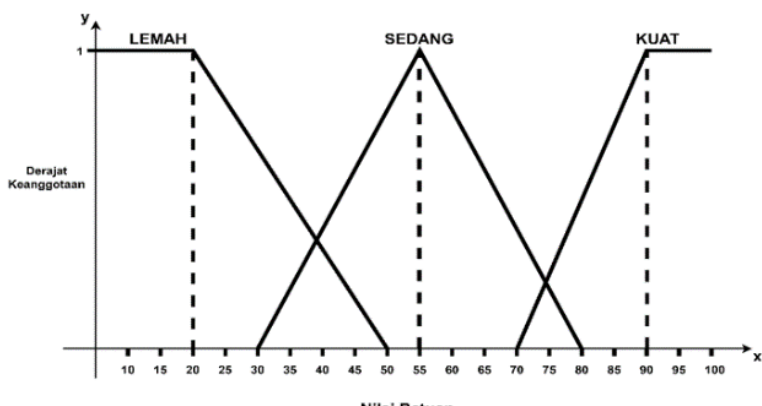

Nilai Batuan

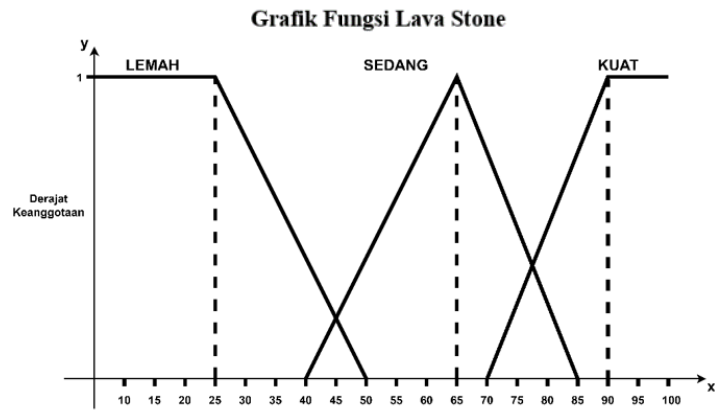

Nilai Batuan

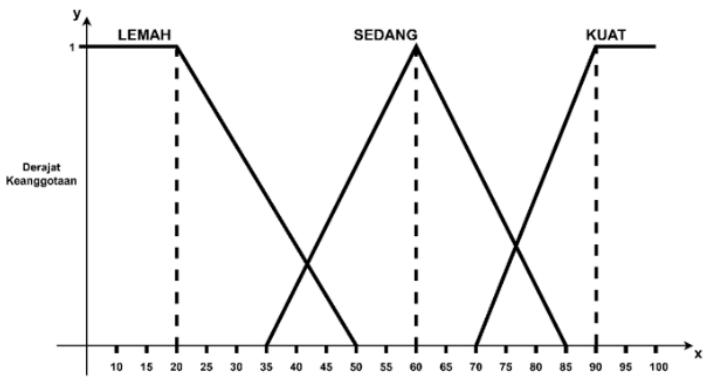

Nilla Batuan

Grafik Fungsi Lime Stone

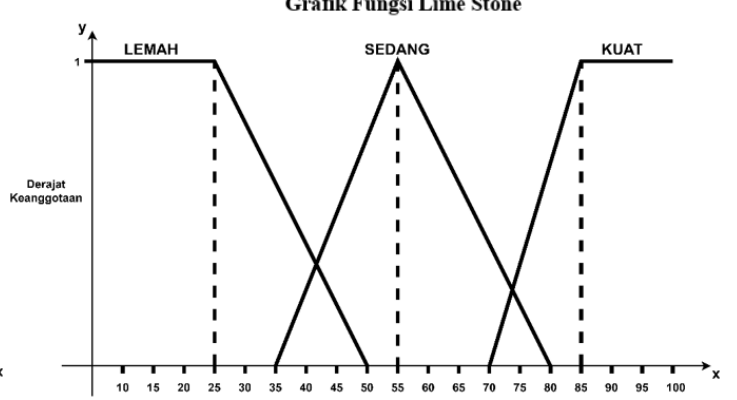

Nilai Batuan

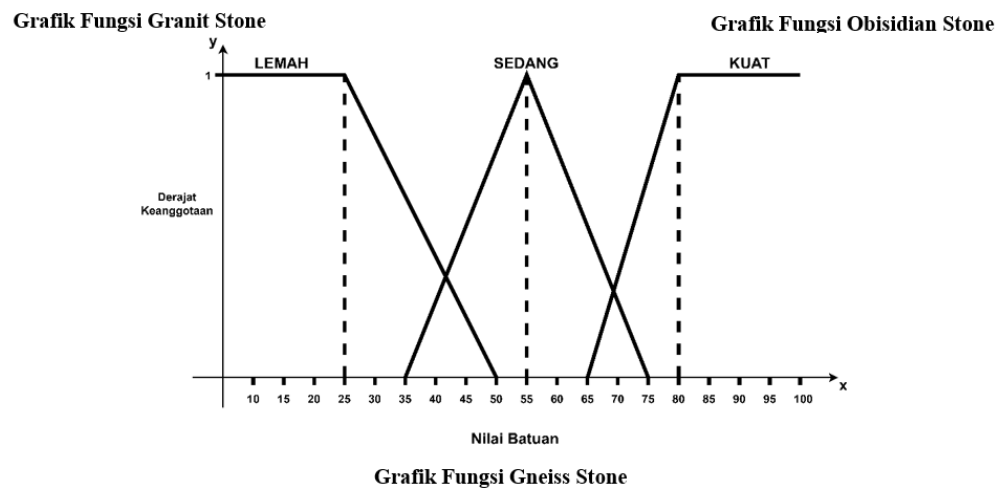

Gambar 2. Grafik keanggotaan untuk batu dasar.

Pada fungsi keanggotaan batu magis ini mempunyai rentang nilai antara 0 sampai 100. Nilai dari batu magis ini juga dibangkitkan dengan nilai random atau acak. Batuan magis ini digunakan untuk menambah akurasi ketepatan kualitas batuan yang diinginkan. Grafik keanggotaannya ditunjukkan pada Gambar 3 berikut.

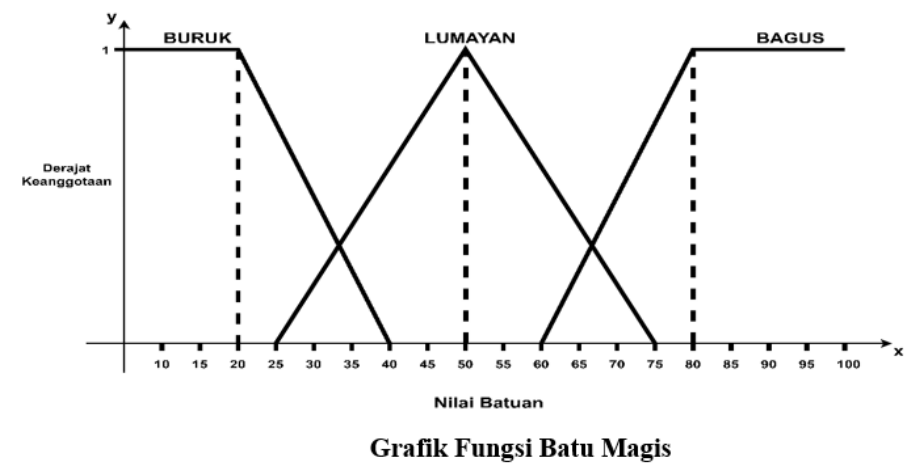

Gambar 3. Grafik keanggotaan untuk batu magis.

Logika Fuzzy untuk Perilaku Dinamis pada Sistem Crafting dalam Game Pembelajaran Aritmatika (Andrean Nugraha Fajero) 
Fungsi keanggotaan dari batu dari batu dasar yang dikombinasi dengan tiga kombinasi batu tersebut ditunjukkan pada Gambar 4 berikut.

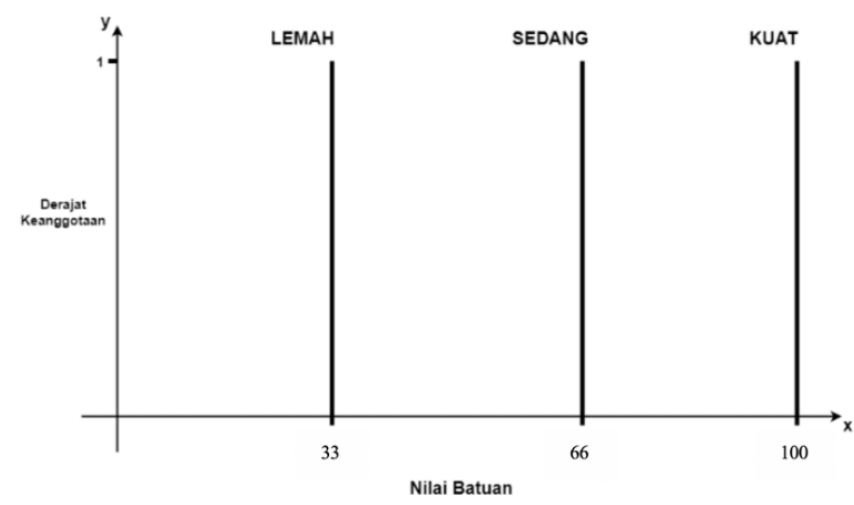

Gambar 4. Grafik keanggotaan untuk batu hasil.

Penentuan nama batu yang didapatkan oleh player diatur dalam Tabel 1 di bawah ini. Sehingga player memiliki pilihan dalam crafting system untuk memilih nama batuan hasil yang diinginkan dengan mengombinasikan batu dasar yang sudah di tentukan untuk menghasilkan suatu batuan baru.

Tabel 1. Kombinasi batuan.

\begin{tabular}{|c|c|c|c|}
\hline \multicolumn{3}{|c|}{ Kombinasi Batu Dasar } & \multirow{2}{*}{$\begin{array}{c}\text { Hasil } \\
\text { Basalt }\end{array}$} \\
\hline \multirow{4}{*}{ Lava Stone } & \multirow{4}{*}{ Batu Magis } & Lime Stone & \\
\hline & & Granit Stone & Diorit \\
\hline & & Obsidian Stone & Andesit \\
\hline & & Gneiss Stone & Gabro \\
\hline \multirow{3}{*}{ Lime Stone } & \multirow{3}{*}{ Batu Magis } & Granit Stone & Liparit \\
\hline & & Obsidian Stone & Breksi \\
\hline & & Gneiss Stone & Marmer \\
\hline \multirow{2}{*}{ Granit Stone } & \multirow{2}{*}{ Batu Magis } & Obsidian Stone & Slate \\
\hline & & Gneiss Stone & Sekis \\
\hline Obsidian Stone & Batu Magis & Gneiss Stone & Milonit \\
\hline
\end{tabular}

\subsection{Bentuk Konten Pembelajaran Aritmatika}

Game dalam penelitian ini memiliki soal dengan tema aritmatika dasar yang harus dijawab oleh player untuk melanjutkan perjalanan untuk mencapai final zone. Hasil dari soal matematika yang harus dijawab oleh player tersebut diwakilkan dengan sebuah batu yang harus di-crafting oleh player. Contoh pengaplikasian batu tersebut yaitu, soal matematika yang tertera $6+2$. Hasil dari contoh soal tersebut adalah 8, maka player harus crafting batuan yang menghasilkan batu Andesit dengan kualitas Sedang untuk dapat membuka gerbang yang tertutup dan melanjutkan perjalanan. Berikut adalah tabel perwakilan batu terhadap hasil angka dari hasil perhitungan soal aritmatika dasar yang tertera di dalam game.

Tabel 2. Kualitas batu.

\begin{tabular}{|c|c|c|c|}
\hline Angka & Model batu & Angka & Model batu \\
\hline 1 & Basalt Lemah & 16 & Breksi Lemah \\
\hline 2 & Basalt Sedang & 17 & Breksi Sedang \\
\hline 3 & Basalt Kuat & 18 & Breksi Kuat \\
\hline 4 & Diorit Lemah & 19 & Marmer Lemah \\
\hline 5 & Diorit Sedang & 20 & Marmer Sedang \\
\hline 6 & Diorit Kuat & 21 & Marmer Kuat \\
\hline 7 & Andesit Lemah & 22 & Slate Lemah \\
\hline 8 & Andesit Sedang & 23 & Slate Sedang \\
\hline 9 & Andesit Kuat & 24 & Slate Kuat \\
\hline 10 & Gabro Lemah & 25 & Sekis Lemah \\
\hline 11 & Gabro Sedang & 26 & Sekis Sedang \\
\hline 12 & Gabro Kuat & 27 & Sekis Kuat \\
\hline 13 & Liparit Lemah & 28 & Milonit Lemah \\
\hline 14 & Liparit Sedang & 29 & Milonit Sedang \\
\hline 15 & Liparit Kuat & 30 & Milonit Kuat \\
\hline
\end{tabular}




\section{Hasil dan Pembahasan}

Pada bagian peneliti akan melakukan pengujian terkait metode Fuzzy Logic yang digunakan untuk menghasilkan nilai pada batuan hasil yang selanjutnya digunakan untuk menentukan kualitas pada batuan hasil tersebut. Jenis metode Fuzzy Logic yang digunakan dalam penelitian ini yaitu metode Fuzzy Sugeno. Perhitungan yang dilakukan ini digunakan untuk membandingkan antara hasil perhitungan nilai parameter input secara manual dengan hasil perhitungan nilai parameter input yang telah diimplementasikan ke dalam game pada crafting system. Dengan adanya perbandingan tersebut peneliti dapat mengevaluasi apakah aksi penentuan kualitas pada batuan yang dihasilkan dapat menyesuaikan dengan aturan yang telah dibuat. Pengujian ini menggunakan 20 soal aritmatika dasar dengan parameter nilai batuan dasar dan jenis kombinasi batu yang berbeda-beda. Nilai dari masing-masing batuan dasar yang didapatkan oleh pemain dibangkitkan secara acak atau random oleh sistem.

Pengujian pertama yang dilakukan ini menggunakan sampel kombinasi yang digunakan yaitu, Lava Stone dengan nilai 20, Lime Stone dengan nilai 40 dan Batu Magis dengan nilai 86.

\subsection{Fuzzifikasi}

Fuzzifikasi dilakukan untuk mengubah nilai masukan tegas crips menjadi nilai yang disesuaikan dengan derajat keanggotaan tiap-tiap batuan. Derajat keanggotaan untuk atribut dari Lava Stone dengan nilai 20, Lime Stone dengan nilai 40 dan Batu Magis dengan nilai 86 adalah:

a. Lemah

Karena kurva berbentuk trapezium maka menggunakan persamaan 2 untuk Lava Stone dan untuk Lime Stone, maka derajat keanggotaannya adalah:

$$
\begin{aligned}
& \mu_{\text {Lava_Lemah }}[20]=1 \\
& \mu_{\text {Lime_Lemah }}[40]=\frac{50-40}{50-20}=0,33
\end{aligned}
$$

b. Sedang

Pada sedang, kurva berbentuk segitiga maka menggunakan persamaan 1 untuk Lava Stone dan Lime Stone, maka derajat keanggotaannya adalah:

$$
\begin{aligned}
& \mu_{\text {Lava_Sedang }}[20]=0 \\
& \mu_{\text {Lime_Sedang }}[40]=\frac{40-35}{60-35}=0,2
\end{aligned}
$$

c. Kuat

Perhitungan untuk variabel kuat menggunakan persamaan ke 2 karena berbentuk trapezium untuk Lava Stone dan Lime Stone, maka derajat keanggotannya adalah:

$$
\begin{aligned}
& \mu_{\text {Lava_Kuat }}[20]=0 \\
& \mu_{\text {Lime_Kuat }}[40]=0
\end{aligned}
$$

Kemudian derajat keanggotaan untuk Batu Magis dengan nilai 86 adalah:

a. Buruk

Berdasarkan persamaan ke 2 untuk Batu Magis, maka derajat keanggotaannya adalah:

b. Lumayan

$$
\mu_{\text {Magis_Buruk }}[86]=0
$$

Berdasarkan persamaan ke 1 untuk Batu Magis, maka derajat keanggotaannya adalah:

c. Bagus

$$
\mu_{\text {Magis_Lumayan }}[86]=0
$$

Berdasarkan persamaan ke 2 untuk Batu Magis, maka derajat keanggotaannya adalah:

$$
\mu_{\text {Magis_Bagus }}[86]=1
$$

\subsection{Mesin Inferensi}

Mesin Inferensi merupakan langkah selanjutnya setelah fuzzifikasi. Nilai dari masing-masing batu dasar yang telah diubah ke dalam derajat keanggotaan kemudian dilakukan operasi menggunakan aturan Fuzzy yang telah dibuat . Nilai derajat keanggotaan masing-masing batu tersebut dicari nilai terkecil dari nilai derajat keanggotaan yang ada pada aturan yang memenuhi syarat. Proses pencarian nilai minimum tersebut mengakibatkan nilai $\alpha$-predikat akan bernilai 0 , maka tidak perlu dilakukan pada setiap aturan yang ada. Aturan yang memenuhi syarat tersebut yaitu:

a. IF Lava Lemah $A N D$ Lime Lemah $A N D$ Magis Kuat THEN Basalt Lemah

$$
\begin{aligned}
\alpha-\text { predikat }_{1} & =\mu_{\text {Lava_Lemah }} \cap \mu_{\text {Lime_Lemah }} \cap \mu_{\text {Magis_Bagus }} \\
& =\min \left(\mu_{\text {Lava_Lemah }}[20], \mu_{\text {Lime_Lemah }}[40], \mu_{\text {Magis_Bagus }}[86]\right)
\end{aligned}
$$




$$
\begin{aligned}
& =\min (1 ; 0,33 ; 1) \\
& =0,33
\end{aligned}
$$

Karena Basalt Lemah, maka berdasarkan Gambar 4, nilai dari $z_{1}=33$

b. IF Lava Lemah $A N D$ Lime Sedang $A N D$ Magis Kuat THEN Basalt Sedang

$\alpha-$ predikat $_{2}=\mu_{\text {Lava_Lemah }} \cap \mu_{\text {Lime_Sedang }} \cap \mu_{\text {Magis_Bagus }}$

$$
\begin{aligned}
& =\min \left(\mu_{\text {Lava_Lemah }}[20], \mu_{\text {Lime_Sedang }}[40], \mu_{\text {Magis_Bagus }}[86]\right) \\
& =\min (1 ; 0,2 ; 1) \\
& =0,2
\end{aligned}
$$

Karena Basalt Sedang, maka berdasarkan Gambar 4, nilai dari $z_{2}=66$

\subsection{Defuzzifikasi}

Kemudian untuk nilai tegas dari $z$ dapat dicari dengan menggunakan metode rata-rata terbobot dengan rumus:

Sehingga nilai $z$ adalah:

$$
z^{*} \frac{\sum a_{1} z_{1}}{\sum a_{1}}
$$

$$
\begin{aligned}
& z=\frac{\left(a-\text { predikat }_{1} * z_{2}\right)+\left(a-\text { predikat }_{2} * z_{2}\right)}{a-\text { predikat }_{1}+a-\text { predikat }_{2}} \\
& z=\frac{(0,33 * 33)+(0,2 * 66)}{0,33+0,2} \\
& z=45,45
\end{aligned}
$$

Dari nilai $z$ tersebut dapat disimpulkan bahwa kombinasi dari Lava Stone dengan nilai 20, Lime Stone dengan nilai 40, dan Batu Magis dengan nilai 86 akan menghasilkan batu baru berdasarkan tabel kombinasi batuan yang bernama Basalt dengan nilai 45,45 dan berdasarkan pada tabel kondisi penentu kualitas batu terhadap nilai batu 45,45 akan menghasilkan kualitas batu sedang. Tabel 3 menunjukkan implementasi pada crafting system di dalam game untuk menghasilkan berbagai jenis dan kualitas batu.

Tabel 3. Tabel hasil sistem crafting.

\begin{tabular}{ccccc}
\hline No & Batu Dasar 1 & Batu Dasar 2 & Batu Dasar Magis & Batu Hasil \\
\hline 1 & Lava[20] & Lime[40] & Magic[86] & BASALT[45,45] \\
\hline 2 & Lava[47] & Obsidian[84] & Magic[42] & ANDESIT[95,64] \\
\hline 3 & Obsidian[94] & Gneiss[26] & Magic[29] & MILONIT[40,436] \\
\hline 4 & Lava[33] & Obsidian[72] & Magis[22] & GABRO[58,142] \\
\hline 5 & Lava[24] & Gneiss[54] & Magic[37] & BREKSI[33] \\
\hline 6 & Lime[8] & Obsidian[29] & Magic[94] & LIPARIT[62,107] \\
\hline 7 & Lime[42] & Granit[72] & Magic[37] & MARMER[55,6875] \\
\hline 8 & Lime[71] & Gneiss[45] & Magic[25] & MILONIT[54,521] \\
\hline 9 & Obsidian[85] & Gneiss[44] & Magis[10] & SLATE[84,937] \\
\hline 10 & Granit[77] & Obsidian[75] & Magic[33] & DIORIT[33] \\
\hline 11 & Granit[83] & Gneiss[54] & Magic[27] & SEKIS[36,666] \\
\hline 12 & Granit[12] & Lava[60] & Magic[23] & LIPARIT[33] \\
\hline 13 & Granit[42] & Gneiss[17] & Magic[31] & BASALT[83] \\
\hline 14 & Granit[34] & Lime[40] & Magic[9] & BREKSI[49,923] \\
\hline 15 & Lime[74] & Lava[93] & Magic[28] & GABRO[70,146] \\
\hline 16 & Lime[42] & Obsidian[14] & Magic[89] & SLATE[33] \\
\hline 17 & Lava[71] & Gneiss[55] & Magic[96] & DIORIT[91,854] \\
\hline 18 & Granit[20] & Obsidian[5] & Magic[14] & Magic[73] \\
\hline 19 & Granit[82] & Lava[56] & Magic[85] & MARMER[100]
\end{tabular}




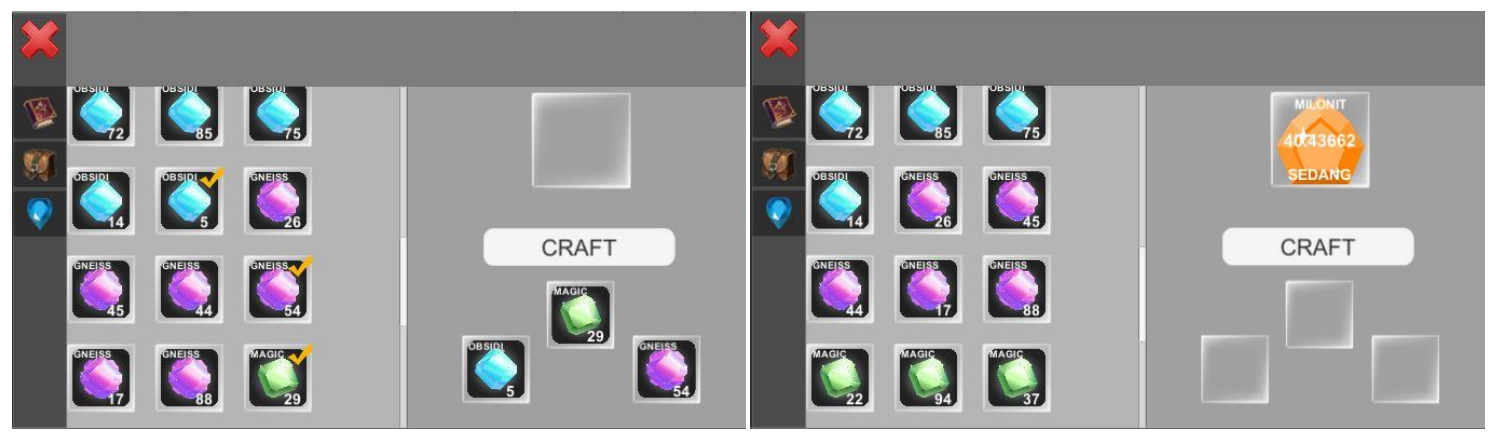

Gambar 5a. Proses Crafting System.

Gambar 5b. Hasil Crafting System.

Dari Gambar 5a dan 5b tersebut merupakan penampilan dari antarmuka crafting system yang merupakan pusat mekanisme permainan dengan sistem crafting dalam penelitian ini. Gambar 5a adalah proses crafting yang menghasilkan batu seperti ditunjukkan pada Gambar $5 \mathrm{~b}$.

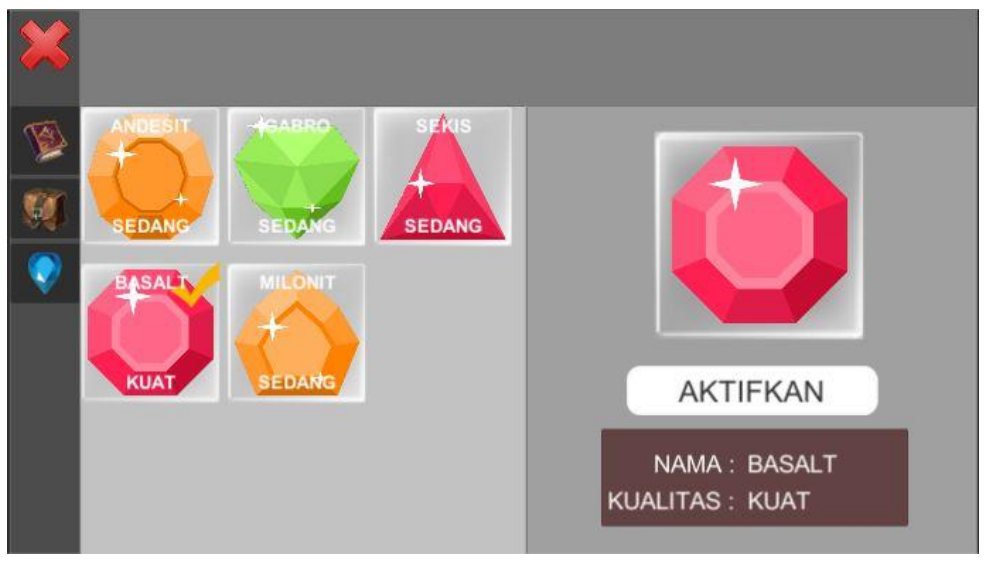

Gambar 6. Proses Crafting System

Gambar 6 menampilkan inventory batuan yang berhasil diciptakan dari proses crafting. Batu hasil tersebut selanjutnya diletakkan di panel equipment. Pada panel equipment tersebut terdapat tombol pengaktifan dan informasi tentang batuan yang dipasang. Tombol pengaktifan digunakan untuk membuka gerbang level selanjutnya. Hasil yang didapatkan menggunakan Fuzzy dapat memberikan perilaku dinamis pada sistem crafting yang ada.

\section{Kesimpulan}

Metode Fuzzy berhasil membuat kualitas dari batuan yang di-crafting terlihat dinamis dengan menyesuaikan parameter input dari batuan dasar 1, batuan dasar 2, dan batuan magis. Beberapa pengujian yang dilakukan terhadap penentuan kualitas batu yang berhasil di-crafting telah sesuai dengan aturan yang sudah dibuat berdasarkan kondisi nilai atribut dari batuan dasar 1, batuan dasar 2, dan nilai batuan magis. Dengan demikian, sistem crafting memiliki perilaku dinamis berdasarkan kualitas batu input-nya.

\section{Daftar Pustaka}

[1] Permendikbud, "Standar Isi Pendidikan Dasar dan Menengah”, Jakarta, 2016.

[2] Prasetyari, "Pengembangan Media Pembelajaran Game Edukasi Berbasis Role Playing Game Padaa Materi Persamaan Linier Dua Variable Bagi Siswa Kelas VII SMP Negri 1 Ungaran," Jurnal Pendidikan Matematika, Vol. 5, No. 8, 2016.

[3] TIMSS2015, “TIMSS 2015 International Results in Mathematics,” Boston, 2015.

[4] D. W. Brata, B. Santoso, J. C. Beck, and M. Wade, "Pembelajaran Matematika dengan Operator Dasar untuk Anak Sekolah Dasar Berbasis Mobile," J. Ilm. Inform, Vol. 1, No. 1, 2016.

[5] Sistem Pendidikan Nasional, "Undang-Undang No.20 Tahun 2003," Dep. Pendidik. Nas., Jakarta, 2003.

[6] Pantelidis, Veronica, "Reasons to Use Virtual Reality in Education and Training Courses and a Model to Determine When to Use Virtual Reality," Themes in Science and Technology Education,

Logika Fuzzy untuk Perilaku Dinamis pada Sistem Crafting dalam Game Pembelajaran Aritmatika (Andrean Nugraha Fajero) 
Klidarithmos Computer Books, Athens, 2016 .

[7] A. Barredo and P. Garaizar, "Flow Paths: A standalone tangible board system to create educational games," Int. J. Emerg. Technol. Learn., vol. 10, no. 4, pp. 11-14, 2015.

[8] L. F. Braghirolli, J. L. D. Ribeiro, A. D. Weise, and M. Pizzolato, "Benefits of educational games as an introductory activity in industrial engineering education," Comput. Human Behav., vol. 58, pp. 315-324, 2016.

[9] F. Yeni, Y. Hasan, and Tarmansyah, "Efektifitas Game Edukasi Untuk Meningkatkan Kemampuan Penjumlahan Bagi Anak Kesulitan Belajar Di Min Koto Luar, Kecamatan Pauh,” E-JUPEHku (Jurnal Ilm. Pendidik. Khusus) Vol.2 No. 3, 2013.

[10] A. Grow, M. Dickinson, N. Wardrip-Fruin, M. Mateas, and J. Pagnutti, "Crafting in Games," Digit. Humanit. Q., 2017.

[11] H. Nasution, "Implementasi Logika Fuzzy pada Sistem Kecerdasan Buatan," J. ELKHA Vol 4 No 2, 2012.

[12] A. B. Harisa, H. Haryanto, and H. A. Santoso, "Model Tingkat Kesulitan Dinamis Berbasis Logika Fuzzy," Semin. Nas. Teknol. Inf. dan Multimed., 2016.

[13] S. I. Pangestu, H. Haryanto, E. Dolphina, J. T. Informatika, F. I. Komputer, and U. Nuswantoro, "Item Adaptif Menggunakan Logika Fuzzy Mamdani Pada Game Bertema Adaptive Item Using Mamdani Fuzzy Logic in River Sanitation," CCIT J. Vol 11 No 1, 2018. 